\title{
LEGAL EDUCATION: TEACHING THE ISSUE OF EXTORTION IN INTERNATIONAL LAW
}

\author{
Osama Elias Ahmed Qadi \\ PhD student, Department of Criminal Law, Moscow, RUDN University, RUSSIA, \\ qadi ossama@yahoo.com
}

\begin{abstract}
The Law Institute of RUDN University pays much attention to innovations in the legal field, carrying out some research in both the legal field and contemporary teaching the students. The correct teaching and learning is a must in today's rapidly changing education so that future graduates can compete with their peers.
\end{abstract}

Extortion has been known to humankind for a long time. Nowadays, this phenomenon has not lost its prevalence at all, but rather, on the contrary, it has gained particular relevance. New methods of extortion have become known: unlike in the past, when the most widespread was blackmail: the threat of denunciation, disclosure of shameful, compromising information, now they are extorting not only money or property, although this is still very common. Requirements to conclude transactions on unfavorable terms for the victim, get a job, vote for the "right" candidate to the board of directors, and so on have become widespread. Blackmail is just one way of extortion.

In addition to these methods, to obtain the necessary things, information, or services from the victim, criminals use many other methods, such as kidnapping threats of violence with their "demonstrative" use. There are also progressive methods - unfavorable conditions are created for the victim's business activity, service, and alike. For obvious reasons, the extortion was and is exceptionally latent.

It seems essential to improve the criminal law measures to combat this negative social phenomenon in current conditions. Moreover, in the context of the globalization of modern society, the fight against this crime requires the consolidation of the efforts of different countries at the international legal level.

The article's conclusions could be of importance while learning and teaching in the Russian universities following the novelties in the legislation and the necessity of the learners to catch up with the modern educational requirements.

Keywords: legal education, university degree, extortion, blackmail, crime, property, criminal law, legislation.

\section{INTRODUCTION}

People have faced extortion as a type of crime throughout the history of human society. At the present stage, this right violation is still widespread and has gained particular relevance in all countries. Criminals are constantly inventing new ways of extortion. Moreover, the fight against these evils is acquiring international 
significance.

The term extortion is used when referring to the crime of obtaining money or property using threats to harm the victim or his property or family. Extortion can include the threat of damage to the victim's reputation or financial well-being. Anything that was obtained through extortion, including consent, was illegally obtained, and the perpetrator committed a criminal offense. To explore this concept, consider the definitions of extortion.

Extortion is understood as a violently selfish crime against property, the essence of which is the extraction of property benefits, which does not contain signs of theft.

Extortion also means the requirement to surrender property or the requirement to perform any operations with the property of the victim when used under threats, reprisals, violent actions, as well as in the event of a threat to commit any action with the property of the victim, its damage, in the event of a threat issuance or disclosure of incriminating information regarding the victim or persons related to him by kinship or other relations, or other information, the disclosure of which may harm the interests of the victim or persons associated with him. [4].

There are various types and methods of extortion. One of the most common methods of extortion is blackmail - the threat of exposure or dissemination of defamatory information.

Nowadays, the subject of extortion is not only money or property, but also the requirement to conclude transactions on unfavorable conditions for the victim, employment, voting for the "right" candidate to the board of directors, and alike.

Also, to obtain money, necessary things, information, or services from the victim, besides these methods, criminals use many other methods, for example, kidnapping threats of violence with its "demonstrative" use. There are also methods such as creating unfavorable conditions for the victim's activities in business, in the service, and some others.

Cyber extortion is extortion on the Internet, this type of extortion has become widespread today. Typically, with such extortion, the company receives an e-mail message stating that the attackers received confidential information and threaten to release it to the public. Also, cybercriminals can carry out attacks on the company's servers. In this case, the condition for non-disclosure of information is transferring money to the specified account.

\subsection{Qualification of Extortion}

Each such crime differs from the rest of similar ones by subjective and objective signs. There is a need for an accurate assessment of each such act to differentiate responsibility and individualize punishment, i.e., the need for the correct criminal law qualifications. To do this, it is necessary to understand the nature of this crime in the context of criminal law, having studied the corpus delicti and its qualified types established by the legislator [1].

Among other things, the study of statistical reports of law enforcement agencies leads to the conclusion that extortion is revealed almost constantly and, in general, is a fairly rare crime. Furthermore, this conclusion is incorrect. When the country is mired in domestic extortion and large-scale blackmail, and the victims no longer believe in the help of law enforcement agencies and the force of the law, the creation of a clear legislative framework in this direction is the responsibility of the state and a necessary direction of activity for legal scholars. All this requires careful research work in this area. It is necessary to develop such a legislative structure that will most fully cover the existing manifestations of extortion [4].

It should be noted that extortion does not apply to embezzlement since the seizure of someone else's property is outside the scope of this corpus delicti. This, in particular, is one of the critical signs of the qualification of this crime. However, like embezzlement, extortion is a mercenary crime that encroaches on someone else's property and therefore has some similarities with them (embezzlement).

The composition of extortion is enshrined in law; for example, in the Russian Federation, this type of crime is contained in Art. 163 of the Criminal Code of the Russian Federation, and is found in chapter 21, "Crimes against property," section VIII "Crimes in the sphere of the economy." The generic object is normal economic relations, and the specific object of extortion can be various links between property. It should also be borne in mind that not only property ties are the object of this type of crime, and the nature of the threat should be studied. Other objects of extortion can include life, health, the reputation of a victim, legitimate interests [1].

Characteristically, property relations are legally defined as the main object of legal protection, placing the 
rule of law under consideration in the chapter of crimes against property, and not, say, in chapter 16, "Crimes against life and health" or in chapter 17 "Crimes against freedom, honor, and dignity of the individual." Extortion infringes primarily on someone else's property, has mercenary motives and the goal of profit, and the threat to the health or reputation of a victim is a means of achieving the set goal - taking possession of the victim's property [3].

The subject of extortion is property. This crime begins with the requirement that the victim gives up his property or the right to it or to act concerning this property regardless of whether these requirements were met by the victim or not. As a rule, demands are immediately reinforced by threats, although they may not coincide in time, and it does not matter for the qualification of the culprit's actions whether he intended to carry out his threats in reality. It is enough that the victim perceived these threats as real [1].

What are the differences between extortion and racketeering? Racket is classified as a form of organized crime, and in many cases, it contains extortion. Also, the criminal prosecution for crimes that are carried out within RICO framework includes cases of extortion related to officials who pursue the goal of obtaining certain services or actions from them, up to the termination of the investigation of criminal acts. This also includes the so-called "protection racketeering," when a criminal group extorts "money to protect" residents or companies in a particular territory, using threats against people or businesses, which in case of nonpayment of funds, they will be subjected to violent actions.

Let us consider the differences between extortion and bribery. As for extortion, this crime impacts officials, and there are often attempts to bribe them. These crimes differ from each other in the methods used by criminals. In the case of bribery, the amount of money is transferred to an official who, in turn, undertakes to fulfill certain requirements of the persons who gave the bribe. Moreover, in the case of extortion, the perpetrator's demands are based on threats and the use of violence.

Let us consider the differences between extortion and robbery or crimes based on the appropriation of someone else's property are. Extortion also refers to property crimes involving the violent appropriation of someone else's property. As in the case of extortion, the crime of robbery includes threats against the victim the use of violence to appropriate someone else's property.

If, out of revenge for the refusal to comply with the requirements, the perpetrators used violence, the deed should be qualified as extortion associated with a specific crime against the person. This moment should not be confused with the use of violence in the course of extortion in order to achieve criminal goals, which is provided for by qualified and especially qualified (depending on the consequences) elements of extortion [4]. To all of the above, it must be added that if the perpetrator destroyed or damaged someone else's property to achieve a criminal goal, then the deed will be qualified as a real aggregate of crimes under Art. 163 and Art. 167 of the Criminal Code of the Russian Federation, believing that this property belongs to the victim. Although there may be cases when the perpetrator was mistaken and damaged or destroyed property, to which the victim has nothing to do. Such an error will not matter for the qualification of the culprit's actions.

It is also essential that to qualify the actions of criminals under Art. 163 of the Criminal Code of the Russian Federation, it is necessary to have in their actions the means of taking possession of other people's property, that is, threats, provided for by the disposition of the norm [1].

Thus, extortion is a fairly common crime today. Being one of the foundations of the financial system of organized crime and given its internally conditioned latency, this type of crime poses an increased social danger.

\section{APPROACHES TO THE PHENOMENON OF EXTORTION IN INTERNATIONAL LAW}

The appeal to law-making experience in foreign countries is primarily due to intensive integration processes in various spheres of interstate relations. The Russian legal system is actively entering the global legal field, bringing various branches of legislation in line with generally recognized principles and international legal acts.

The legislation of other countries contains specific approaches to determining the corpus delicti of extortion, identifying these concepts in criminal law. Therefore, they are interested in law-making in Russia. The laws of foreign states consider the processes and mechanisms for regulating liability for these crimes. It should be recognized that at present, such crimes as extortion and blackmail have become widespread and have become a frequent occurrence in legal practice [2].

In the case of extortion and blackmail, Russian criminal law defines an independent corpus delicti. Also, in many foreign countries, these crimes are classified separately. In particular, in France, the Criminal Code 
contains chapters "On extortion" and "On blackmail." The Dutch Criminal Code contains a chapter "Extortion and blackmail," the Tunisian Criminal Code includes a chapter "Extortion, blackmail, misappropriation, bankruptcy." It is worth noting that the legal definitions of these crimes have characteristic but insignificant, distinctive features, which are due to differences in the legal systems of these countries. However, as for the punishment for these crimes, these criminal law norms have significant differences in different countries.

Let us highlight the most characteristic features of the legislative approach to solving the problems under study in individual countries. So, Art. 312-1 of the Criminal Code of France defines extortion as "obtaining by violence, the threat of violence or coercion to obtain either a signature, an obligation or a refusal of an obligation, or secret information, or material values or any other property [3].

When comparing the content of this norm with the corresponding norms of the Criminal Code of other foreign countries, their similarity is visible. So, for example, we observe a similar approach of the legislator to the formation of the composition of extortion in Part 1 of Art. 317 of the Criminal Code of Holland [4].

In the same way, the objective and subjective signs of the composition of extortion in Art. 196 of the Criminal Code of San Marino, Art. 156 of the Criminal Code of Switzerland, Art. 249 of the Criminal Code of Japan, Art. 282 of the Criminal Code of Poland, and some others. [3].

The act of extortion is considered a felony in most U.S. States, punishable by fines, incarceration, probation or parole, and restitution payable to the victims. When a public official extorts someone by misusing his/her official position to obtain some advantage, profit, or benefit, it is called "extortion under color of official right."

The legal definition of the crime of extortion varies from state to state. In some states, only acts of extortion performed by public officials are charged under the crime of extortion, while these acts, when committed by a private individual, are charged as blackmail. When interstate commerce is involved in the act of extortion, either physically or by use of computers, Internet, phone, or mail, it may be charged as a federal crime.

Whether or not the threat is carried out does not determine whether the crime of extortion has been committed. As long as a verbal, written, or printed threat is made; there is an intention to purposefully or willfully carry out the threat, and the victim reasonably believes that the threat is real; this is sufficient. Additionally, the threat can be directed toward someone other than the intended victim, such as his/her family member or loved one. Extortion is closely related to bribery and robbery since they are all forms of theft/larceny. However, with robbery, the money or property is taken by force or intimidation, against the victim's will and without his/her consent.

Although rare, in some states, the crime of extortion can also result in a civil lawsuit for damages under tort law. In these cases, it is necessary to show proof of the threat of violence, proof that the extortion resulted in damage/injury, and that the person being sued caused the damage. [4].

Along with the coercive forms of extortion, a well-known form of extortion is its form of "defense," which implies that the perpetrator will not perform specific actions due to which harm may be caused. In return, the victim must regularly transfer certain amounts of money to the extortionist.

If a criminal extorts money in return for hiding certain information, without using any violent actions, but with the intention to force the victim to pay money, then such a crime is considered blackmail, following separate legislative definitions.

This type of crime can be extortion on an enormous scale, which is undertaken by the whole organization or by its representative. Such a crime is called racketeering, specified in legislation, particularly in the Racketeers and Corrupt Organizations Act (RICO).

The California Extortion Act classifies extortion according to two criteria: the purpose of the extortionist and the means used by the perpetrator. The statute prohibits a person (1) from accepting property, another person; (2) the use of violent methods concerning the victim, the use of threats and other methods of intimidation, causing harm.

Based on this federal law, the fact is indicated that crimes related to extortion also include the use of threats in the interstate sphere. Threats to federal officials to obtain benefits through the use of their official position qualify as extortion, which is approved by federal law.

For a specific category of officials, several regulations may relate to extortion. In particular, it may be laws that do not allow customs officials to put forward requirements for additional duties at the border.

Specific nuances concerning the definition of the corpus delicti of extortion are indicated in the Criminal Code of the Federal Republic of Germany in the section "Robbery and extortion." Section 253 of the Criminal Code 
defines extortion; however, it is formulated by the legislator somewhat unsuccessfully, which causes specific difficulties for legal analysis [4].

The structure of extortion, as in the Criminal Code of Tunisia, Japan, Poland (Art.282 of the Criminal Code) 11 , is designed according to the type of material and is considered completed from the moment the property of the victim or another (close) person is damaged. Therefore, paragraph 3 of $\S 253$ of the Criminal Code of the Federal Republic of Germany states that attempted extortion is punishable.

Thus, in the era of globalization, several states such as Russia, France, Germany, Holland, the USA, San Marino, Poland, Tunisia, Japan, and many others are improving their national legislation to combat extortion at the international level in the legal sphere.

\section{CONCLUSION}

Although there are differences, the terms extortion and blackmail are often used interchangeably. Extortion is the illegal and intentional use of threats to one's person or property, coercion, or fraudulent claims of right of public duty (such as impersonating a police officer) to take money, goods, property, other things from a victim against his/her will. These threats can be violence, physical harm, criminal prosecution, or public exposure of harmful or secret information that would damage a person's reputation and/or standing in the community. When the threat is to reveal embarrassing, harmful, and/or shameful information about the victim to his/her friends, co-workers, associates, family members, or to the public in general, this is generally defined as blackmail and is usually considered a type of extortion.

In connection with the particular severity of this type of crime, in our days, it is necessary to improve the criminal law mechanisms and the legislative framework to combat this evil at the international legal level. Thus, in the era of globalization, the fight against extortion needs to be united to states in the legal sphere.

\section{ACKNOWLEDGMENT}

This paper has been supported by the RUDN University Strategic Academic Leadership Program.

\section{REFERENCE LIST}

1. Akshita Piplani. (2015) Extortion // Law Times Journal. URL: https://lawtimesjournal.in/

2. Ave Mince-Didier. (2021) Extortion: Laws, Penalties, and Sentencing // Criminal Defense Lawyer. URL: https://www.criminaldefenselawyer.com/crimepenalties/federal/Extortion.htm? cf chl managed th =pmd 8f1a03817e3757ad1c08c1e12f0500 cb f91524ba-1629191247-0-gaNtZGzNAs2jenBszQjO

3. Extortion // Legal Dictionary. (2015). URL: https://legaldictionary.net/extortion/

4. Extortion // US Legal. (2021). URL: https://criminallaw.uslegal.com/crimes-against-property/extortion/

5. Extortion //Justia/ (2021). URL: https://www.justia.com/criminal/offenses/white-collar-crimes/extortion/

6. Extortion law in California // Robert Helfend. (2021). URL: https://www.robertmhelfend.com/criminaldefense/extortion/

7. Extortion and Blackmail Law // HG.org. (2021). URL: https://www.hg.org/extortion.html

8. Ugolovnyj kodeks Rossijskoj Federacii” ot 13.06.1996 № 63-FZ (red. ot 07.04.2020) (s izm. i dop., vstup. v silu s 12.04.2020). (in Russian) URL: http://www.garant.ru (date of access 14.03.2020).

9. Grudinin N.S. (2018) Sovremennoe sostoyanie i statistika vymogatel'stv v Rossijskoj Federacii // Nauchnyj vestnik ,Kryma. (in Russian) No 2 (13). - p. 17.

10. Dolya, B.G. (2007) Algoritm dejstvij sledovatelya pri rassledovanii vymogatel'stv v zavisimosti ot sposoba peredachi predmeta vymogatel'stva // YUridicheskaya mysl'. (in Russian) No 1 (39). - pages 86-87.

11. Dolya, B.G.(2007) Metodika rassledovaniya vymogatel'stva (po materialam Severo-Zapadnogo federal'nogo okruga): dis. ... kand. yurid. nauk. - S.-Pb., (in Russian). - 190 pages

12. Kompleksnyj analiz sostoyaniya prestupnosti v Rossijskoj Federacii i raschetnye varianty ee razvitiya: 
analiticheskij obzor / YU.M. Antonyan, D.A. Brazhnikov, M.V. Goncharova i dr. - M.: FGKU «VNII MVD Rossii», 2018. 86 pages. (in Russian)

13. Kupcova, K.O. (2018) Special'nye mery protivodejstviya vymogatel'stvam // Rossijskij sledovatel'. (in Russian) No 6. - pages 29-31.

14. Kupcova, K.O. (2011) Prestupnoe povedenie i mekhanizm soversheniya vymogatel'stva // YUridicheskoe obrazovanie i nauka. (in Russian) No 3. - pages 32-37.

15. Melent'ev, A.V. (2020) Extortion: criminal law characteristics and modern trends // Education and law No 4. DOI 10.24411/2076-1503-2020-10458 URL: https://cyberleninka.ru/article/n/vymogatelstvougolovno-pravovaya-harakteristikai-sovremennye-tendentsii

16. Tsoi, L.V. Criminal legislation of Russia and foreign countries on responsibility for extortion // Altai Bulletin of State and Municipal Service. 2017. URL: https://elibrary.ru/item.asp?id=32866418

17. Tereshchenko, L.S., Shebanov D.V. On some controversial aspects of the definition of extortion // Business in law. №6. 2013. URL: https://cyberleninka.ru/article/n/o-nekotoryh-spornyh-aspektahopredeleniya-vymogatelstva

18. Susloparov, I.A. Extortion in Russian legislation: a retrospective analysis // Bulletin of Perm University. №4 (30). 2015. URL: https://cyberleninka.ru/article/n/vymogatelstvo-v-rossiyskom-zakonodatelstveretrospektivnyy-analiz

19. Nikitin, Yu.A. The content of blackmail: issues of theory and practice // Bulletin of the Omsk Law Academy. 2016. № 3 (32) URL: https://cyberleninka.ru/article/n/soderzhanie-shantazha-voprosy-teoriii-praktiki

20. Ganchenko, O.I. Comparative study of the provisions of the criminal legislation of the neighboring countries on responsibility for blackmail // Society and Law. 2012. № 4 (41) 